\title{
22. LITHOLOGIC-GENETIC CHARACTERISTICS OF SEDIMENTS IN A SECTION AT SITE 463, DEEP SEA DRILLING PROJECT LEG 621
}

\author{
P. P. Timofeev, N. V. Renngarten, and V. V. Eremeev, Geological Institute of the U.S.S.R. \\ Academy of Sciences, Moscow, U.S.S.R.
}

\section{INTRODUCTION}

Site 463 is situated in the northwestern part of the underwater slope of the Mid-Pacific Mountains, at a depth of 2525 meters, the hole penetrated 820 meters of sedimentary rocks and stopped before reaching the basaltic basement. The Mesozoic part of the sedimentary section is roughly 765 meters thick; the upper 50 to 55 meters are Cenozoic.

Deposits of the upper Barremian, Aptian, Albian, Cenomanian, and Turonian are most completely presented here. During Barremian-Turonian time, thick $(\sim 565 \mathrm{~m})$ sediments accumulated. These are overlain by relatively thin $(\sim 80 \mathrm{~m})$ deposits of the lower Turonian-Coniacian and upper Campanian. The Mesozoic part of the section terminates with Maastrichtian beds, the total thickness being 130 meters. A hiatus begins at the end of the upper Maastrichtian and ends at the beginning of the Eocene. Cenozoic deposits, approximately 55 -meters thick, are represented by lower Eocene, upper Oligocene, upper Miocene, lower and upper Pliocene, and Pleistocene.

Sediments are dominantly biogenic, some purely carbonate, some siliceous carbonate, and some essentially siliceous. The rocks composing the middle part of the lower Aptian deposits (Cores 69-74) are an interesting exception. These rocks are biogenic and pyroclastic. Quite different rocks, not biogenic, are found in the lowermost part of the section. These are breccias and sandstones, consisting of fragments of limestones, mollusk shells etc.

The shipboard party subdivided the section at Site 463 into four lithologic units, and the uppermost unit (Unit I) was in turn subdivided into two sub-units.

The base of the section (Unit IV) contains rhythmically alternating clastic (shallow-water) and pelitomorphic (deep-water) limestones.

The overlying unit (Unit III) includes different rocks: limestones, marls, claystones, tuffs, and calcareous-siliceous rocks containing up to $4.3 \%$ organic carbon.

The second unit (Unit II) is composed of multicolored limestones.

The lower sub-unit of Unit I (i.e., Sub-unit IB) consists of foraminifer-nannofossil and nannofossil sediments of different degrees of lithification (limestone, chalk). The upper sub-unit (Sub-unit IA) is composed of nannofossil oozes.

\footnotetext{
1 Initial Reports of the Deep Sea Drilling Project, Volume 62.
}

The shipboard subdivision of the section was made during visual examination of the cores, on the basis of such features as color, degree of lithification, grain size, and sediment composition.

Laboratory treatment of the material (microscopic and other investigations of rocks) enabled us to specify in detail the lithologic characteristics of the section, establish facies and mineralogical criteria for subdivision of the section, and elucidate certain questions of genesis of the deposits and the history of accumulation of the section as a whole.

\section{LITHOLOGIC AND FACIES ANALYSIS OF THE SEDIMENTARY SECTION, SITE 463}

Laboratory analysis of the core material from Site 463 was intended to (1) reveal facies environments of accumulation of primary sediments yielding Meso-Cenozoic rocks, (2) reproduce the geological history of formation of this section, reflected in particular in sedimentary structures and characteristic of post-sedimentary changes of rocks.

Extra attention was paid to one of the main principles of genetic lithology that can be formulated as follows: the characteristics of each sedimentary rock are subdivided into two groups: (1) all features inherited from the initial sediment and called primary or genetic; this group of features reflects the facies conditions of accumulation and the first stages of diagenesis of sedimentary material; (2) features acquired by a rock at various stages of post-sedimentary changes in the process of formation and diagenesis of the pile; these features are called secondary, or superimposed; they can mask considerably the primary features of a sediment.

At Site 463 , the primary features are (1) composition of faunistic remains and relationships of biogenic forms of $\mathrm{SiO}_{2}$ and $\mathrm{CaCO}_{3}$, (2) the proportion of clastic (redeposited) material, clay, and biogenic remains in the sediment, (3) admixture of ash particles, (4) presence of sapropelic material, (5) character of primary lamination and degree of bioturbation, (6) diagenetic microlamination in ooze. Primary (early-diagenetic) features include authigenic montmorillonite, zeolite, and siderite appearing in decomposed volcanic glass under influence of mineralized thermal waters in fresh sediment. Secondary features of rocks are (1) recrystallization of organic remains, (2) leaching of biogenic silica in some cases and biogenic carbonate in others, (3) transformation of organic $\mathrm{SiO}_{2}$ into globular opal (in a stage of late diagenesis), (4) transformation of amorphous $\mathrm{SiO}_{2}$ into a crystalline variety optically determined as chalcedony and 
by X-ray examination as cristobalite, (5) replacement of skeletal remains of radiolarians by calcite, and in filling of voids in tests and sinuous fissures in hard rock with calcite and barite. Traces of post-sedimentary changes of rocks gave an idea of geological factors controlling accumulation of the sedimentary section. For example, leaching of biogenic silica from a rock followed by replacement by calcite and filling of fissures with calcite (sometimes together with barite) suggests penetration of alkaline solutions in an already lithified rock. Abundant pyroclastic material in rocks, with indications of diagenetic reworking and participation of mineralized waters, testifies to an outburst of volcanic activity in corresponding areas of the ocean, and to the proximity of geothermal fields.

As mentioned above, the Meso-Cenozoic sediments are divided into four parts (units), according to the gross features of rocks and their general composition. The study of primary features of initial sediments and secondary transformations of rocks showed that such a subdivision is expedient; we suggest that the boundaries of some units be changed, and that the units themselves be characterized by different lithologic-genetic features. In addition sub-units were recognized in all units.

Thus, four successive series (units) of deposits were outlined in the Cenozoic-Mesozoic section at Site 463. Each of the units reflects the general environment of sedimentation, which was rather stable within the region. This environment and corresponding deposits are called a macrofacies. The regular change of macrofacies through the section enables us to establish the major stages of development of geological events within a region. It is natural that in any part of a region local, lessstable conditions of sedimentation could exist. As a result, the sediments acquired specific features in addition to those peculiar to the given macrofacies. These more-local conditions of accumulation of sedimentary material are given the name facies. A macrofacies may include several facies. If facies conditions originated from a regular combination of sediments differing in grain size and composition, each distinguished sediment is regarded by us as a genetic type. A facies in turn can be represented by several genetic types.

Figure 1 presents a scheme of subdivision of the section into units and sub-units, and brief characteristics (in historical succession) of sedimentation conditions on a regional scale (macrofacies).

The numbers of units and other subdivisions of the pile begin from the top and proceed downward, as adopted aboard the Glomar Challenger; description of the pile is carried out from bottom to top in the section, i.e., in chronological order.

\section{Unit IV, Macrofacies 4 (Cores 75-92)*}

Two sharply different types of rocks alternate in this series of deposits: (1) clastic carbonate rocks containing fragments of oolitic and organic-detrital limestones,

\footnotetext{
- No samples were collected below Core 88 .
}

etc., (2) biogenic, pelitomorphic limestones with skeletal remains of radiolarians.

All rocks of the macrofacies are characterized by strong lithification and secondary carbonatization. Fissures and micropores filled with granular calcite (sometimes with barite) are common. Radiolarian remains almost everywhere do not preserve primary meshy microstructure: they are represented now by globular opalby globular opal with chalcedony, or by pure chalcedony (cristobalite). In some cases, as result of secondary processes, radiolarian skeletons were either entirely leached out (and the rocks acquired micropore structure), or metasomatically replaced by calcite $\left(\mathrm{CaCO}_{3}\right.$ content increased to $95 \%$ ). One may think that the process of changing the primary opal skeleton of radiolarians proceeded by stages: at one stage of diagenesis the organogenic $\mathrm{SiO}_{2}$ dissolved and reprecipitated as globular opal; then, during epigenesis, the opal was recrystallized into cristobalite (chalcedony).

It is noteworthy that no foraminifer tests were observed in rocks of Unit IV.

\section{Clastic Limestones or Calcareous Breccias (Cores 90, 88, 83-85, 79-81)}

The clastic material of these rocks contains unsorted (clasts range from a millimeter to $2-3 \mathrm{~cm}$ ) and commonly angular fragments of organogenic-detrital and oolitic limestones (with granular, recrystallized cement); limestones with micro-lumpy structure; mollusk shells (some silicified); numerous single (broken and unbroken) oolites and their aggregates; a negligible admixture of silty and smaller particles of quartz, feldspar, chlorite, glauconite, and montmorillonite. There are also remains of radiolarian skeletons formed of chalcedony, and rare fragments of siliceous sponge spicules. Clastic material is cemented by pelitomorphic carbonate that sometimes includes sinuous, thin veins of calcite. It is noteworthy that almost every fragment of limestone, tests, oolites, etc. is coated by a thin, cryptocrystalline film that frequently grades into the cement of rocks and therefore hardly can be recognized. This film likely originated during transportation of the materials under conditions of dense, paste-like flow.

\section{Pelitomorphic Biogenic Limestones (Cores 91-92, 89, 86-87, 82-83, 78, 75-78)}

The ground mass of limestones is cryptocrystalline and strongly lithified; it contains rare semi-dissolved coccoliths-indicators of the biogenic nature of the original sediments. The amounts of radiolarian remains are variable; siliceous sponge spicules are common. Besides silica, there are appreciable amounts of clay matter (dominantly montmorillonite) in the carbonatefree part of these rocks; particles of quartz, feldspars, and chlorite are present. The thinnest clay interbeds (and short lenses) enriched with carbonaceous matter of sapropelic origin are an exception. In some places, pyrite forms small authigenic accumulations and frequently develops after radiolarians. Radiolarian skeletons formed by globular opal usually include montmorillonitic particles within the globules. 


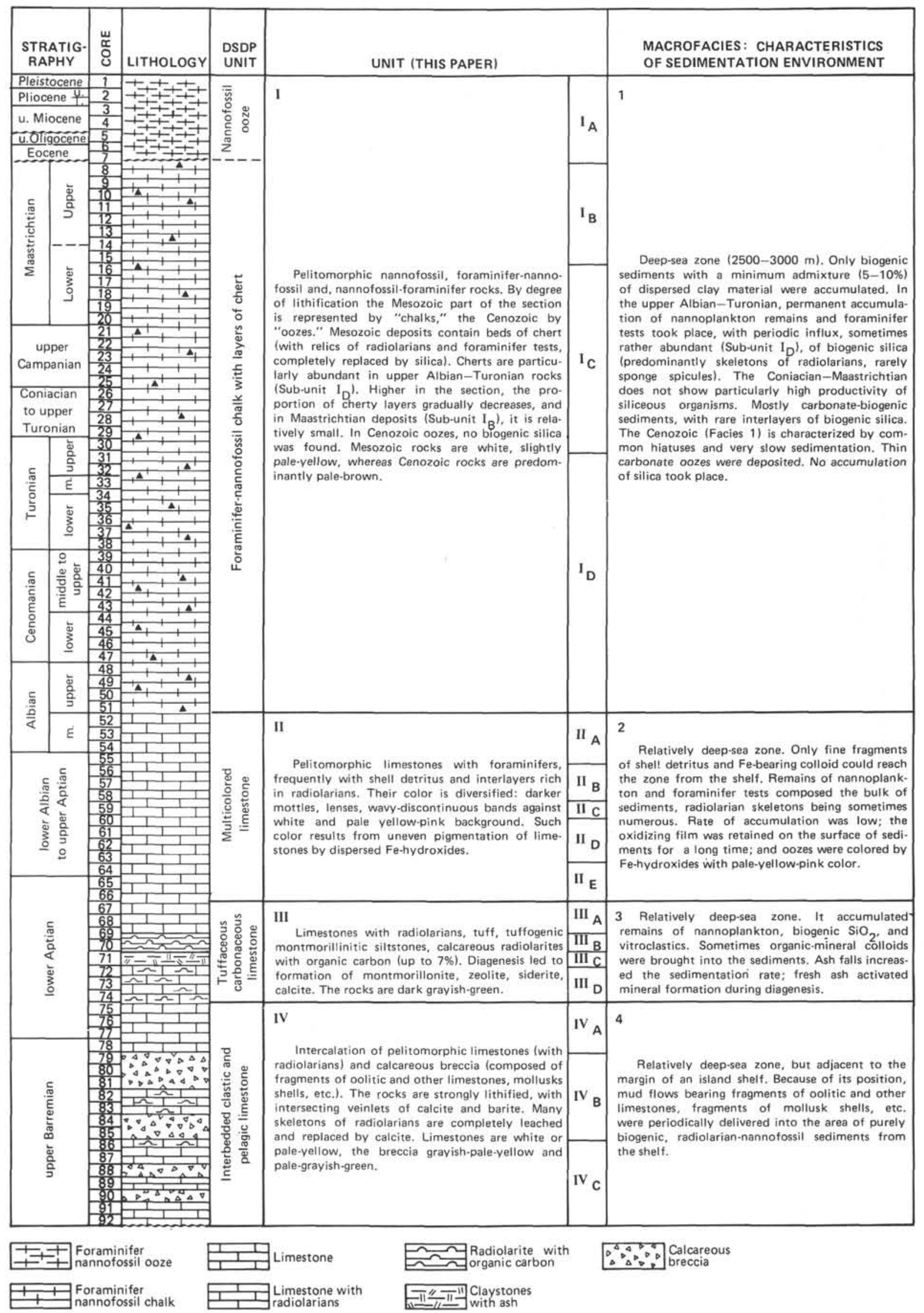

Figure 1. Lithologic units and macrofacies at Site 463 (according to the results of this study). 
Clastic limestones form approximately four independent horizons within Unit IV, whereas pelitomorphic limestones form six. Breccias of all three horizons are similar, their origin likely being related to one genetic type of sediments. Pelitomorphic limestones, on the contrary, are diverse; this fact shows pecularities of initial sediments and differences in the processes of their subsequent transformations.

There is a certain regularity in the distribution of clastic and biogenic limestones and lithogenetic types of pelitomorphic limestones through the section. It allows us to divide Unit IV into at least three sub-units. Each sub-unit includes deposits of one facies zone with characteristic features of sediments (genetic types).

Figure 1 gives a detailed scheme of alternation of rocks differing lithologically (and genetically) and composing Unit IV, facies distinguished by us (sub-units), and lithologic-genetic types of deposits. Unfortunately, we had very poor core recovery in this interval $(12 \%)$. Therefore, the boundaries between heterogeneous beds were drawn conditionally.

Sub-unit IVC, facies $4 c$ (Cores $86-92$ ) is characterized by predominance $(\sim 70 \%)$ of pelitomorphic varieties of carbonate rocks over clastic ones $(\sim 30 \%)$. Pelitomorphic limestones are frequently composed of carbonate material (90-92\%); skeletal remains of radiolarians are replaced by calcite; thin veins of calcite and barite are frequently observed as well. Clay matter is in negligible amounts. Near brecciated horizons, the rocks contain fine shell detritus and single fragments of limestones.

Sub-unit IVB, facies $4 \mathrm{~b}$ (Cores 79-85) differs from the underlying one by a reverse ratio of thickness of pelitomorphic $(\sim 30 \%)$ and clastic limestones $(\sim 70 \%)$. The main difference consists in the character of pelitomorphic rocks; they originated from nannofossil oozes enriched in clay and radiolarians. The clay matter forms small lenses and thin interbeds; some clay interbeds are colored brown by colloidal sapropelic organic matter. The rocks show pinnate, wave-like, thin discontinuous horizontal lamination.

Sub-unit IVA, facies 4 a (Cores 75-78) is composed solely of pelitomorphic limestones, which are rather homogeneous. The carbonate-free part of the rocks, amounting to not more than 10 to $15 \%$, is represented by clay and amorphous $\mathrm{SiO}_{2}$. The groundmass of limestones is represented by cryptocrystalline carbonate and displays microporosity at the expense of completely leached, tiny radiolarian skeletons. Only at the very base of the sub-unit (Core 77, Section 1), radiolarian remains are replaced by calcite; there are veins filled with calcite.

This series of deposits (Unit IV), characterized by alternation of lithologically and genetically different rocks, is in the focus of attention of researchers. Yet, there is no unanimous opinion on general environment of accumulation of initial sediments composing this series. The materials obtained from one site only, and poor core recovery, do not allow us to speak with confidence of the origin of the section as a whole. Nevertheless, certain assumptions are possible.
We believe that biogenic planktonic nannofossil and radiolarian oozes accumulated in a relatively deep-water zone. But that zone adjoined a less-deep-water zone, a zone of the peripheral part of island relief. Therefore, dislocation of boundaries of these zones took place periodically (likely because of tectonic factors). As a result, biogenic carbonate-siliceous sediments alternated with limy-clastic, brecciated ones. When judged by composition of clastic material of breccias, it follows that the parent rocks were represented by oolitic, lumpy, and skeletal clastic limestones of shallow-water genesis (with remains of echinoderms, mollusks, etc.). By the time of redeposition these limestones had already been heavily lithified, partly recrystallized, and partly silicified. The shallow-water limestones appear to be older than Barremian.

Shallow-water sediments in the central parts of the oceans are known to be due to the existence of islands of volcanic or tectonic origin (intense rise of separate blocks). Clastic material of Barremian breccias was supplied into the sedimentation area by means of dense paste-like flows. These flows were likely distributed over the periphery of the shelf.

It is noteworthy that the deposits grouped by us into Unit IV underwent some post-sedimentary transformations. They were strongly lithified; nannofossil remains were recrystallized into a homogeneous pelitomorphic mass, and most radiolarian skeletons were replaced by either reprecipitated globular opal or cristobalite. Some changes in rocks could have proceeded because of hydrothermal processes. For instance, complete removal of $\mathrm{SiO}_{2}$ from rocks and replacement of the latter by carbonate should have taken place under influence of concentrated alkaline solutions.

\section{Unit III, Macrofacies 3}

\section{(Core 67, Section 3 to Core 74, Section 3)}

This series of deposits, of lesser thickness $(\sim 45 \mathrm{~m})$ than the underlying Unit IV is represented by lithologically different, but genetically related rocks: radiolarian limestones, tuffaceous siliceous-montmorillonitic claystones, calcareous radiolarites enriched with sapropelic material, etc. General conditions of sediment accumulation of macrofacies 3 (Unit III) were considerably differed from those of macrofacies 4 (Unit IV), in the following: (1) almost no fragments of limestones were supplied to the zone of sediment accumulation; biogenic sedimentation was persistent; (2) volcanic ash (sometimes abundant) was constantly supplied to sediments. As result of abundant ash falls, specific post-sedimentary (diagenetic) processes were proceeding in sediments: authigenic montmorillonite, zeolite, and siderite formed.

The regular change of lithologically different rocks through the section enabled us to subdivide Unit III into four sub-units that correspond to four facies types of initial sediments.

Sub-unit IIID, facies 3d (Core 71, Section 4 to Core 74 , Section 7) has the greatest thickness $(\sim 30-35 \mathrm{~m})$ and consists of rocks similar to pelitomorphic limestones of Unit IV. The main components of Sub-unit IIID are 
biogenic pelitomorphic limestones rich in radiolarian remains, with fragments of small siliceous sponge spicules, and thin interbeds and micro-lenses of clay matter. Radiolarian remains are formed in most cases of chalcedony or chalcedony together with globular opal; radiolarian skeletons with primary opal organogenic structure are rare; in some interbeds, radiolarian remains are replaced by calcite. The rocks can be broken (across the bedding) by thin fissures filled with calcite or chalcedony.

Near the base of Sub-unit IIID, there occurs an interbed (Core 74, Section 1, 15-16 cm) of pure tuff: pyroclastic glass with a slight admixture of plagioclases and hyalobasalts, with single skeletons of radiolarians; the carbonate content of the tuff is low, roughly 10 to $15 \%$.

In Core 73, Section 3, a bed of calcareous breccia was recorded. It is similar to clastic limestones of Unit IV. The breccia consists of fragments of oolitic, skeletalclastic and micro-lumpy limestones, fragments of large tests, echinoderm remains, etc. Fragments of effusive rocks of andesitic composition sometimes can be observed (phenocrysts of entirely calcitized plagioclases are submerged in the pilotaxitic groundmass). Cement in the breccia is pelitomorphic and granular calcite.

In Core 71 , Section 4, 41-56 cm, single fragments of skeletal-detrital limestones are observed in pelitomorphic limestones with radiolarians. Many skeletons of radiolarians are carbonatized here.

Pale-green authigenic montmorillonite was recognized in all rocks of Sub-unit IIID; it usually fills the central part of a radiolarian skeleton (the outer coating remains opal).

Sub-unit IIIC, facies 3 Core 71 to Core 71 , Section 3) has a very small thickness $(\sim 4.5-5 \mathrm{~m})$, but is characterized by great diversity and pecularity of rocks. These are mostly radiolarian-montmorillonitic (zeolitized in interbeds) and montmorillonitic (with authigenic siderite) claystones. All these rocks resulted from biogenic, mostly radiolarian oozes saturated with fine ashy material. The latter has been diagenetically altered; authigenic montmorillonite, zeolite, siderite, and calcite were formed. Fine fragments of volcanic glass can be seen under a microscrope (in immersion specimens) in fine fractions of these rocks. Worth attention is the character of siliceous and carbonate material of rocks of Subunit IIIC. Besides relics of skeletal silica (radiolarian, less frequently siliceous sponges) one can often see a reprecipitated globular opal that develops irrespective of radiolarian skeletons forming lenses. These appear as diffuse mottles of a homogeneous isotropic mass. Most radiolarian remains were replaced by pale-green montmorillonite or an aggregate of colorless zeolite crystals (clinoptilolite). It should be emphasized that in all rocks of Sub-unit IIIC no skeletons replaced by globular opal or chalcedony (cristobalite) were observed. This shows that the processes of metasomatic replacement of radiolarian remains by montmorillonite and zeolite took place in the earliest stages of diagenesis.

Biogenic carbonate in the rocks is almost absent. It may be that a relatively high rate of ash accumulation prevented deposition of considerable amounts of such fine and light material as remains of nannoplankton. It is noteworthy that in places where the montmorillonitic groundmass of claystones contains coccoliths the latter are well preserved and do not bear distinct traces of dissolution. This again indicates that montmorillonitization of the whole sediment took place at some early stage of diagenesis. In some interbeds (e.g., Core 70, Section 7), the groundmass consists of reprecipitated calcite enclosing remains of radiolarians (with biogenic opal skeleton or entirely replaced zeolite), relics of volcanic glass fragments, and authigenic siderite. Equant and irregularly shaped granular aggregates (sometimes with obscure spherulitic structure) of authigenic, ironcontaining carbonate (siderite?) are present in montmorillonitic claystones as well.

Sub-unit IIIB, facies $3 b$ (Core 70, Section 6 to Core 69, Section 3), (up to 9-m thick) contains specific rocks that require extra attention. These are chiefly calcareous and siliceous, with a relatively high content of organic carbon (up to 4.5-7.0\%). Timofeev and Bogolyubova carried out a detailed study of these rocks and organic matter and described the results in a separate paper (this volume).

Some siliceous rocks are almost carbonate-free (5-7\% $\mathrm{CaCO}_{3}$ ), some appreciably calcareous (up to $35 \%$ $\mathrm{CaCO}_{3}$ ). Silica in the form of chalcedony (cristobalite) and globular opal replaces skeletal remains of radiolarians and siliceous sponge spicules. Remains of radiolarians prevail in almost all rocks. Therefore, radiolarites are the main components of Sub-unit IIIB. In some interbeds, however (Core 70, Section 3) sponge spicules are of importance, so the rocks can be called radiolarian-spicularite. In addition to silica that is spatially related to remains of micro-organisms, the reprecipitated amorphous $\mathrm{SiO}_{2}$ forms irregular lens-shaped areas; sometimes it makes up a homogeneous groundmass of rocks.

Organic carbon is represented by brown colloidal matter and tiny, rounded, opaque bodies which, as suggested by L. I. Bogolyubova, are remains of micro-algae (cysts of dinoflagellates).

The rocks are characterized by thin, interrupted, wave-like, lens-shaped micro-lamination due to the distribution of organic colloid and small short lenses of pale-green montmorillonite which is elongated in the same direction. In all lenses, montmorillonite is metacolloidal: it is recrystallized into a wavy and radially extinguishing, brightly polarizing mass. These lenses show no scaly terrigenous structure of clay material. The montmorillonite in lenses appears to be authigenic; it precipitated from colloidal solution and underwent recrystallization in the process of diagenesis. The lenticular and wave-like distribution of organic matter and authigenic montmorillonite appears to be a result of separate coagulation of a complex organic-mineral hydrogel that saturated siliceous ooze sediments. While precipitating out of the colloidal solution, hydrosols became isolated; this imparted a corresponding microlamination to the diagenetically transformed sediment.

In Sub-unit IIIB there occurs an interbed (Core 70, Section 3) of carbonatized tuffaceous siliceous rock. It is pale-greenish-yellow and contains small fragments of 
acidic volcanic glass, authigenic aggregates of zeolite, and relics of radiolarian skeletons; it consists mostly of reprecipitated carbonate $\left(\mathrm{CaCO}_{3} \sim 8.9 \%\right.$; grains diffuse).

In the overlying section, the rocks gradually become more carbonate-rich, the organic-carbon content decreasing.

Sub-unit IIIA, facies $3 a$ (Core 67, Section 3 to Core 69 , Section 2) is roughly 9 -meters thick. It is composed mostly of greenish-gray, pelitomorphic nannofossil limestones, with interbeds of calcareous radiolarites $\left(\mathrm{CaCO}_{3}\right.$ $\sim 35 \%$ ). Radiolarian remains in the latter are formed by globular opal together with chalcedony. Relics of the former admixture of ashy particles are visible. Pyroclastic fragments of hornblende and pyroxene grains are rarely recognized. In Core 69 , Section $3,15-17 \mathrm{~cm}$, radiolarian skeletons in the sediment are carbonatized. In some rocks of Sub-unit IIIA equant aggregates of authigenic, strongly oxidized siderite are dispersed in the pelitomorphic mass.

\section{Unit II, Macrofacies 2 (Cores 52-67, Section 2)}

This unit is about 130-meters thick, and consists of rocks which sharply differ from the rocks of the lower units (III and IV). These are pelitomorphic limestones with foraminifer tests and, commonly, fine shell detritus (usually undefinable; ostracode valves are rarely recognized in Cores 61,62 ); single fragments of large mollusk shells are observed as an exception (Cores 61, Section 1; 62, Section 1; 65, Section 2; 66, Section 2). The limestones are slightly clayey $(10-15 \%$ of particles $<0.01 \mathrm{~mm}$ ), biogenic silica being not so representative as for instance for rocks of Unit III. According to Dean (this volume), the content of free $\mathrm{SiO}_{2}$ in rocks of Unit II is, on the average, close to $27 \%$, whereas in rocks of Unit III it amounts to about $64 \%$. Beds enriched with biogenic silica (remains of radiolarians) are present in Cores 53, 55, 58, and 66, where the $\mathrm{SiO}_{2}$ content can reach $54 \%$. In places where skeletons of radiolarians provide large accumulations, they are composed of finegrained, crystalline silica. If radiolarian remains were scattered in ooze, many skeletons either entirely leached away, or were completely replaced by calcite.

The groundmass of limestones is pelitomorphic, almost entirely recrystallized, with semi-dissolved coccoliths hardly visible.

The limestones of Unit II are distinguished by their color and structural pecularities. While describing the moist core material on board Glomar Challenger, these rocks were called multi-colored limestones. In a dry state, they are of pale colors: greenish, pale-yellow, pinkish pale-yellow. The "texture" of limestones visible with the naked eye is very peculiar. In a section across the bedding of the limestone, there appear micropinnate, lenticular, discontinuous-horizontal, and other laminations. However, a thorough study raises doubts whether this reflects the primary lamination of the primary sediments, i.e., the lamination functionally related to dynamics of bottom waters. Any primary lamination is known to be expressed or emphasized by something. It can be due to differences in grain size or material composition of beds, various angles of inclinations of oblique series of laminae, etc. The character of lamination sometimes emphasizes bedding planes of terrigenous micaceous and coaly particles, etc. In the given case, the bedding in so-called "laminated" rocks does not prove primary and related to the character of migration of water masses during sediment accumulation. It may be said to be false bedding that appeared in diagenesis of sediments and owes its origin to corresponding distribution of meta-colloidal Fe-hydroxide in sediments. It should be emphasized that the common paleyellow and pale-pink color of rocks is related to slight but even pigmentation of carbonate material with finely dispersed Fe-hydroxides.

Unit II is composed mainly of rather homogenous rocks, and is not subdivided as easily as underlying units. Nevertheless, a certain succession of beds is recognized in this series, too; this enables us to distinguish five sub-units.

Sub-unit IIE, facies 2e (Cores 64-67, Section 1) includes pelitomorphic limestones enriched with radiolarian remains (filled with finely crystalline silica) in interbeds. The limestones contain small, scattered foraminifer tests, and oval and rounded micropores from leached radiolarians. Aggregates of authigenic siderite (strongly oxidized) are present.

Sub-unit IID, facies 2d (Core 60, Section 2 to Core 63) includes pelitomorphic limestones with small and relatively large foraminifer tests. There are small amounts of shell detritus enriching separate interbeds (Core 36, Section 1, 62-63 cm). Tests of small foraminifers in the lower part of the sub-unit may be filled with calcite, whereas in the upper part they are usually hollow.

Sub-unit IIC, facies 2c (Cores 59-60, Section 1) unites a rather peculiar group of rocks. These are pelitomorphic limestones with small foraminifers, rare remains of radiolarians, and a small amount of shell detritus. Almost all remains of radiolarians are replaced by calcite, and some are entirely leached. Appreciable pyritization is characteristic. Pyrite develops after discrete tests of foraminifers, and forms aggregates stretching along the lamination of rocks. In some places, small clay lenses and hardly recognizable patches of colloidal organic carbon are noticed. At the base of this sub-unit (Core 60, Section 1, 75-78 cm), there occurs a pelitomorphic limestone devoid of faunal remains, and rich in aggregates of oxidized authigenic siderite.

Sub-unit IIB, facies $2 \mathrm{~b}$ (Cores 56-58) consists of pelitomorphic limestones with small foraminifer tests (with hollow chambers), and (very characteristic) great amounts of shell detritus containing fragments of ostracode valves. The arrangement of shell detritus emphasizes the horizontal lamination of rocks.

Sub-unit IIA, facies 2a (Cores 52-55) consists of pelitomorphic limestones with small foraminifers (with hollow chambers) and interbeds (Cores 53, 55) enriched with radiolarians. The latter are represented by microand cryptocrystalline silica; their content in limestones can reach $50 \%$.

Accumulation of sediments of Unit II proceeded in a rather deep-water oceanic environment, where mostly foraminifer and nannofossil material was supplied, ad- 
mixed periodically with shell detritus (fragments of ostracode valves, etc., and sometimes fragments of mollusk tests). The latter were brought directly from the area of the island shelf. The presence in some rocks of leached or calcite-replaced skeletons of radiolarians, and also clearly authigenic siderite, suggests to us that during formation of the deposits ash was present, and the subsequent penetration of mineralized thermal solutions could have taken place, although not systematically.

\section{Unit I, Microfacies 1 (Cores 1-51)}

This unit has a thickness of about 450 meters, and is composed of rocks genetically associated with deepwater biogenic sediments. This series of deposits covers a large time interval from late Albian to Pleistocene, inclusively.

In the Albian-Turonian, accumulation of nannofossil-foraminifer and foraminifer-nannofossil oozes was proceeding, this carbonate material frequently being associated with radiolarian remains (less frequently sponge spicules: Core 33,CC). During later Cretaceous time (Coniacian-Maastrichtian), the participation of biogenic silica in formation of oozes was gradually decreasing. Cenozoic sediment accumulation was already essentially biogenic carbonate.

During drilling, the siliceous interbeds produced breccias, and variously sized fragments of chert were pressed into rather soft Cretaceous rocks.

Contrary to all underlying older rocks consolidated to limestones, the rocks of Unit I are less lithified, especially those of Cenozoic age. Therefore, all Mesozoic rocks (beginning with the upper Albian) from this section were called "chalk," whereas Cenozoic ones were called simply "ooze." All rocks of Unit I contain foraminifer tests that did not undergo any appreciable recrystallization; their chambers are hollow everywhere, and not incrusted with secondary calcite. In cases where oozes were rich in biogenic silica, many tests of foraminifers in post-sedimentary processes were entirely replaced by chalcedony (all their contours remaining). Post-depositional changes in the sediment mainly affected the siliceous oozes; as a result, no primary opal skeletons of radiolarians are preserved. Transformations of amorphous biogenic siliceous material resulted in formation of hard (with chonchoidal fracture), compact siliceous masses of crystalline silica with inclusions of reprecipitated globular opal.

Carbonate rocks, poor in or devoid of siliceous material, have high $\mathrm{CaCO}_{3}$ content $(\sim 95 \%)$. The insoluble residue usually consists of clay matter; sometimes it contains a negligible admixture of silty and smaller particles of quartz, feldspars, and micas. In rocks enriched with silica, the amount of carbonate can fall below $40 \%$ (Core 36, Section 1, 1-3 cm), and in the insoluble residue, besides clay material, there can be numerous radiolarians and nuclei of silicified tests of foraminifers.

Already on board the ship, the fresh core material revealed differences in the character of Cenozoic and Mesozoic rocks, and this enabled us to distinguish Sub- unit IA and Sub-unit IB in the section concerned. Laboratory studies of the core material from the Mesozoic part of Unit I allowed us to single out three sub-units and, consequently to subdivide Unit I into four sub-units.

Sub-unit ID, facies 1d (Cores 31-51) consists of an alternation of chert and soft sediment. The core recovery in this part of the section was consequently very poor. Nannofossil-foraminifer and foraminifer-nannofossil, slightly cemented rocks (chalks) alternate with hard cherts. The latter are diverse: some consist of a homogeneous, recrystallized mass of silica with rare, scarcely visible relics of radiolarians and foraminifers, others of crystalline silica and irregular pieces of opal. In carbonate rocks of this sub-unit, there are usually scattered skeletons of radiolarians and single, entirely silicified tests of foraminifers.

Sub-unit IC facies Ic (Cores 16-30) is composed of foraminifer-nannofossil chalks, with thinner beds of cherts, and rare radiolarians and silicified foraminifers in a carbonate groundmass. The total carbonate content here is higher than in Subunit ID, and core recovery better. Remains of nannoplankton commonly prevail over those of foraminifers.

Sub-unit IB, facies Ib (Cores 8-15) unites foraminifer-nannofossil and nannofossil-foraminifer chalks, already with very rare interbeds of cherts and almost without inclusions of radiolarian skeletons. The total carbonate content is constantly high; the insoluble residue usually consists of clay material; single particles of quartz, feldspar, and mica are rare.

Sub-unit IA, facies Ia (Cores 1-7) includes Cenozoic deposits separated from Mesozoic deposits by a major hiatus (upper Maastrichtian beds are directly overlain by lower Eocene). The total thickness of the Cenozoic series is not great $(\sim 55 \mathrm{~m})$. All the sediments in a dry state are pale-brown, and practically devoid of biogenic silica. The total carbonate content of the oozes is high (up to $99 \%$ ). The insoluble residue consists of clay particles; silt-sized particles of quartz, feldspar, and mica are sporadic; there is coal dust and very typical authigenic fibrous chalcedony (ellipsoidal and rounded grains with a black cross under crossed nicols).

The diversity of rocks of this sub-unit consists in different ratios of nannoplankton and foraminifer remains, and in the degree of sorting of foraminifer tests. When judged by the available samples, the following regularity can be outlined: Eocene-Oligocene sediments (Cores 5-7) abound in nannofossil-foraminifer oozes with small, approximately equally sized tests of foraminifers; in Miocene deposits (Core 4), pelitomorphic nannofossil oozes with rare large tests of foraminifers; the groundmass of Pliocene-Pleistocene oozes consists of nannoplankton remains, with unevenly distributed small and large tests of foraminifers.

The sediments in Core 1 accumulated in a deep-water zone of the ocean $(\sim 2500-3000 \mathrm{~m})$, without any influence on the process of sedimentation of the island shelf. Almost no ashy pyroclastic material was supplied and no hydrothermal processes were recorded throughout the Campanian-Pleistocene. Worth attention is the fact 
that Cenozoic deposits are characterized here by insignificant thickness and frequent hiatuses. The period of formation of this sedimentary series was likely characterized by extra activity of tectonic movements that did not promote the burial of sediments and their lithification, or by increased flow of bottom waters.

\section{CONCLUSION}

These are brief conclusions obtained as a result of our lithologic-facies investigations of the Ceno-Mesozoic section of Site 463 .

1) The formation of the sediments took place far beyond the continental shelf. It was an area in the ocean inaccessible to allochthonous products of erosion from continental land. Purely local autochthonous material was deposited and redeposited in that zone. Mostly biogenic oozes were formed from remains of radiolarians, siliceous sponges, and nannoplankton in some places, foraminifers and nannoplankton in others. There were episodic conditions favorable for accumulation of calcareous breccias, the clastic material was supplied by local source areas of oceanic origin. Outbursts of volcanic activity in the ocean were reflected in the accumulation of great amounts of pyroclastic material; hydrothermal processes become more intense, and the composition of biogenic remains changed (participation of siliceous organisms increased), etc.

2) Four different environments of sedimentation (four macrofacies) are observed. Each macrofacies was characterized first of all by deep waters and remoteness from the area of underwater (or surface) oceanic rises of the island type (Mid-Pacific Mountains). The Mesozoic part of the section clearly shows a certain succession in change in time of deposits of all four macrofacies. This succession enables us to outline four main historical stages respectively in development of the sediments, and to recognize the general tendency in the evolution of sedimentation conditions in the given area of the ocean for the period from late Barremian to early Maastrichtian.

3) The earliest historical stage (macrofacies 4) of accumulation of the above-mentioned deposits covers the period from late upper Barremian to the beginning of the early Aptian. The accumulation area under study was at that time near the island shelf, with a very mobile boundary. Therefore, relatively deep-water biogenic nannofossil-radiolarian sediments frequently alternated with clastic sediments (breccias). Clastic material was brought in by mudflows from the area of denudation of islands. These contained skeletal-detrital, oolitic, and other limestones (surely of shallow-water origin), and andesite-basalt rocks. The next historical stage (macrofacies 3 ) was very short (it occupies only the middle part of the lower Aptian), but very peculiar. Activation of volcanic activity in corresponding regions of the water area is responsible for abundant ash falls in the area of sedimentation. Highly siliceous and vitroclastic sediments appeared, which in the early stages of diagenesis were transformed into montmorillonitic clays. In this period, the flows rich in fragments of limestones, large tests, etc. were not formed, indicating an increased distance to shallow carbonate banks. Only clay and organic carbon (sapropelic) were supplied from the shelf zone. We suggest that separate coagulation of hydrogels occurred in the ooze. This resulted in a fine, lenticulardiscontinuous microstructure of carbonaceous clayeysiliceous sediments. The second stage of sedimentation (macrofacies 2) was proceeding from the end of the early Aptian to the end of the middle Albian. The general environment of sedimentation in the ocean became quite different. Ash falls ceased, and hydrothermal processes synchronous with sediment accumulation were no longer manifest. Radiolarians and sponge spicules were not preserved; remains of nannoplankton and foraminifers became predominant in the sediments. Finely crushed, repeatedly redeposited shell detritus, and ostracode valves supplied by turbidity flows contaminated foraminifer-nannofossil oozes. The sedimentation rate decreased promoting the conversion of all reactive iron into a hydroxide. The sediments were cyclicly colored pale-pink, pale-green, or pale-brown. The last historical stage of Mesozoic sediment accumulation (macrofacies 1b) began after the late Albian and ended in the early Maastrichtian. It was the period when sediment accumulation was proceeding in the deepest-water oceanic environment (2300-3000 m). The process of material accumulation was proceeding very slowly, with large hiatuses, resulting in formation of mostly carbonate-biogenic (foraminifer-nannofossil) oozes. During pre-Coniacian time, appreciable amounts of organogenic silica were periodically supplied to carbonate oozes; this might have resulted in the appearance (during post-sedimentary transformations of sedimentary material) of hard cherty interbeds within slightly lithified chalks. Later, the amount of biogenic $\mathrm{SiO}_{2}$ in sediments gradually decreased, and was very low in the Maastrichtian.

Cenozoic sediment accumulation was proceeding here approximately under the same facies conditions as in the Turonian-Maastrichtian, i.e., at large depths and very slowly, with considerable hiatuses, with almost no accumulation of biogenic silica.

4) From the base upward, the rocks are progressively less lithified. Deposits from the upper Barremian to middle Albian are represented by hard (if not soaked in water) limestones (depth of occurrence $\sim 450-820 \mathrm{~m}$ ). Beginning with the upper Albian and ending in the lower Maastrichtian (depth of occurrence $\sim 55-450 \mathrm{~m}$ ), there is a gradual transition from hard limestones to less and less consolidated rocks (chalk-like and even oozelike). Cenozoic deposits crowning the sedimentary pile and resting at a depth of 55 meters are scarcely lithified and oozy. Noteworthy is the fact that deposits grouped in Units IV and II (depth 585-820 m) are especially strongly lithified. Once can observe that the increasing overburden down-section intensified pressure and hydrothermal processes. The influence of these processes on already-lithified rocks resulted in filling of fissures with calcite and barite, leaching of $\mathrm{SiO}_{2}$ from remains 
of radiolarians, and formation of pseudomorphs of calcite after radiolarian skeletons.

5) Accumulation of Ceno-Mesozoic sediments took place against a background of gradual deepening of the accumulation area and increasing remoteness from shallow-water banks. During the late Barremian to early Aptian, sediment accumulation and diagenesis was strongly affected by regional volcanism. 